\title{
Empreendedorismo Cultural, Aprendizagem e Identidade Territorial: O Desbravamento de Jovens Músicos do Nordeste de Amaralina
}

\author{
Cultural Entrepreneurship, Learning and Territorial Identity: The Journey of Young Musicians of Northeast Amaralina
}

Emprendimiento Cultural, Aprendizaje e Identidad Territorial: el desbravamento de Jóvenes Músicos del Nordeste de Amaralina

Israel Marques Campos Mestrado em Gestão e Desenvolvimento Social/Centro Interdisciplinar em Gestão Social e Universidade Federal da Bahia Pesquisador do Centro Interdisciplinar em Gestão e Desenvolvimento Social http://lattes.cnpq.br/9354032949753717 https://orcid.org/0000-0001-8514-8108 israelmcamposs@gmail.com

Eduardo Davel Pós-Doutorado em Administração pela Nova School of Business and Economics da Universidade Nova de Lisboa (Portugal). Ph.D. em Administração pela École des Hautes Études commerciales de Montreal (Canadá) Professor na Escola de Administração da UFBA http://lattes.cnpq.br/6818628123587050 https://orcid.org/0000-0003-0610-6474 davel.eduardo@gmail.com

Resumo: Este caso estimula aprendizagem sobre a importância da cultura, da identidade territorial, bem como dos desafios, das necessidades e das potencialidades da arte no processo da educação empreendedora. Relatase a jornada desbravadora de jovens que se confrontam com a possibilidade de serem empreendedores da música e que precisam lidar com vários desafios: (a) pensar o empreendedorismo como algo coletivo, (b) considerar as singularidades identitárias de seu bairro e (c) conseguir uma qualificação relevante. Subterraneamente, a jornada é de desafios, surpresas e aprendizagens sobre o que significa ser empreendedor da cultura. O caso pode ser útil tanto para gestores culturais, empreendedores artísticos, educadores, quanto para líderes comunitários que busquem fomentar o desenvolvimento local baseado na arte ${ }^{1}$.

Palavras-chave: empreendedorismo cultural, educação empreendedora, pedagogia artística, identidade territorial, caso para ensino.

\begin{abstract}
This teaching case encourages learning how important culture and territorial identity are, as well as the challenges, needs and potentialities of art for an entrepreneurship education. It is reported the journey of young musicians facing the possibility of becoming a music entrepreneurs and dealing with several challenges: (a) to think of entrepreneurship as something collective, (b) to consider their neighborhood's identity singularities and (c) to achieve a relevant training. Deeply, the journey is plenty of challenges, surprises and chances to learn what it means to be a cultural entrepreneur. This study might be useful not only for cultural managers, art entrepreneurs and educators but also for community leaders who seek to promote local development based on art.
\end{abstract}

Keywords: cultural entrepreneurship, entrepreneurship education, art-based pedagogy, territorial identity, case for teaching.
Resumen: Este caso estimula el aprendizaje sobre la importancia de la cultura, la identidad territorial, así como los desafíos, las necesidades y las potencialidades del arte en el proceso de la educación emprendedora. Se relata la jornada desbravadora de jóvenes que se enfrentan a la posibilidad de ser emprendedores de la música y que necesitan lidiar con varios desafíos: (a) pensar el emprendedorismo como algo colectivo, (b) considerar las singularidades identitarias de su barrio y (c) alcanzar una cualificación relevante. Subterranealmente, la jornada es de desafíos, sorpresas y aprendizajes sobre lo que significa ser emprendedor de la cultura. El caso puede ser útil tanto para gestores culturales, emprendedores artísticos, educadores, como para líderes comunitarios que busquen fomentar el desarrollo local basado en el arte.

Palabras clave: emprendedorismo cultural, educación emprendedora, pedagogía artística, identidad territorial, caso para enseñanza.

\section{Caso Para Ensino}

1.1 Nordeste de Amaralina, 0 Território que Pulsa Música e Desafios

Denny e Marquinhos, dois músicos consagrados em suas carreiras, desenvolvem um projeto social - "DM de Boa" - com jovens do território de Nordeste de Amaralina (Salvador, Bahia), reconhecido pela sua atividade cultural diferenciada, sobretudo, no campo da música. Procuram trabalhar os aspectos sociais, ambientais e artísticos, focando no ensino da música, na inclusão e profissionalização de jovens na música, reciclando materiais para fazer os instrumentos de percussão. Para fomentar o empreendedorismo cultural nesses jovens, Marquinhos e Denny querem formar parcerias com artistas da comunidade, mas ainda não sabem ao certo o que fazer.
Próximo dali, Felipe, Dandara e Carlos, jovens moradores do bairro, conversam sobre o desejo de constituir uma banda. Com seus 18 anos, cada um acaba de concluir a escola e permanece o sonho de fazer parte de uma banda. Nasceram e cresceram participando de festas, saraus, eventos com músicos, artesãos e tantos outros tipos de artistas. Carlos toca percussão, Felipe canta e Dandara toca cavaquinho. Perseguindo esse sonho, decidiram juntar as poucas economias que cada um tinha e comprar um equipamento de som, parcelado em três vezes. Depois de muitos ensaios, os jovens conseguiram tocar em um barzinho na esquina da casa de Carlos. Combinaram com o dono que o cachê seria definido pela contribuição espontânea de cada cliente. Tocaram vinte músicas de pop internacional e três de samba. No final da noite, receberam metade do que tinham investido no equipamento sonoro. Estavam preocupados em como quitar o pagamento completo desta aquisição. 
Felipe: Tocamos várias músicas de sucesso na rádio, que têm clipes estourados na internet, mas o pessoal nem aplaudiu tanto.

Carlos: É verdade. Parece que gostam mais de samba. Eu achava que o povo só gostava de gringo...

Felipe: Pois é, pensando no futuro da nossa carreira, precisamos continuar cantando músicas pops, em inglês.

No dia seguinte, os jovens refletiram juntos: como conseguiremos pagar o equipamento? Como vamos ganhar dinheiro para ajudar em casa? Qual será nosso repertório?

Para pagarem o equipamento, Felipe, Dandara e Carlos resolveram que, além de tocarem na banda, iriam trabalhar como auxiliares administrativos de segunda a sábado, no mercadinho de um tio de Dandara. Na primeira semana de trabalho, eles perceberam que 44 horas de trabalho semanal ocupava muito tempo, além de deixá-los cansados e frustrados pelo trabalho, que não lhes dava prazer.

Certo dia, ao sair do trabalho às 18:00, com o salário do mês, os três jovens foram abordados por um jovem que lhes apontou uma arma e gritou: "passem as carteiras, brothers"!

Felipe: Não temos dinheiro! Somos trabalhadores! Olha para nossa cara, olha para nossa cor! É igual a sua. Deixa a gente ir, por favor.

Agressor: Eu sei que vocês receberam uma grana. Passem agora ou é morte!

Os jovens músicos passaram as carteiras e o agressor saiu correndo. Carlos começou a chorar.

Carlos: O dinheiro para quitar o equipamento de som, se foi... O dinheiro para a marca da banda e para a divulgação, se foi! Muita gente da nossa idade está no crime. Esse cara tocava violão em uma banda, aqui no bairro, mas virou traficante. Agora, ele e o exguitarrista roubam. Muito complicado!

Dandara concordou com a cabeça.

Dandara: A comunidade precisa de alguma ajuda. Poderia ter sido um de nós, roubando outros jovens.

Felipe: Dandara, mas cada um fica com seus problemas. Vamos focar na nossa carreira, certo?

Ficaram em silêncio profundo e foram para suas casas, de cabeças baixas. Pensaram em ir à delegacia de polícia. No entanto, lembraram que da última vez foram tratados como bandidos. Não sabiam o que fazer, nem por onde ir, muito menos como seria possível viver de música.

\subsection{Empreendedores, Nós?}

$\mathrm{Na}$ noite seguinte, ainda muito tristes, os três jovens se reuniram em um barzinho do bairro. Observavam e comentavam sobre os moradores que passavam. Viam muitos artistas e gente que gostava de sambar nos shows, muitos comerciantes indo para suas casas com o que sobrou do dia, duas artesãs que tinham uma banquinha com suas produções. O movimento do bairro era grande.

Nesse momento, Denny e Marquinhos passavam, quando viram o trio de jovens.

Denny: Vocês são daquela banda de samba, não são?
Carlos: Somos sim.

Marquinhos: Prazer em conhecê-los. Eu sou Marquinhos.

Dandara: Eu sou Dandara, ele é Carlos e ele é Felipe.

Marquinhos: Ele é Denny. Queremos fazer um projeto com jovens músicos.

Felipe: Desculpa, fomos assaltados ontem. Não queremos mais fazer projeto. Vai ser trabalho desnecessário.

Carlos: É verdade. Podemos conversar outro dia? Anote meu número.

Denny e Marquinhos pegaram o contato de Carlos, mas não se entusiasmaram pelo tom em que foram recebidos pelos jovens. Estava difícil conseguir jovens músicos para o projeto. No dia seguinte, Marquinhos ligou para Carlos e marcou uma reunião com todos.

Denny: Que bom que vocês aceitaram nosso convite. Estamos pensando em fazer um edital juntos para captar uma grana e ajudar ainda mais jovens, especialmente, a galera que já mexe com artes, a tocar sua carreira, ganhar seu dinheiro, ampliar as possibilidades.

Carlos: É uma boa ideia! Sofremos um assalto horrível. Era um jovem e músico. Podia ser um de nós.

Denny: Pois é, rapaz. Estamos perdendo muitos artistas para a criminalidade. Por isso, queremos fazer um trabalho com artistas. A gente pode empreender!

Felipe: Empreender? A gente quer fazer música e ganhar dinheiro!

Carlos: Oxente ${ }^{2}$, Felipe. Empreender também é ganhar dinheiro! Denny e Marquinhos, muito obrigado pelo convite, o trabalho de vocês é ótimo. Entretanto, estamos focados em nossa carreira, como Felipe disse, beleza? Inclusive, pessoal, não podemos desanimar com o assalto! Amanhã, vai rolar um show de samba. Vamos curtir depois do trabalho!

Dandara: Poxa, Denny e Marquinhos, eu curti a proposta de vocês. Podemos pensar em uma parceria. Vamos curtir o show que Felipe falou?

Denny: Vamos nessa!

O show acontecia em Nordeste de Amaralina. Denny chamou Marquinhos, Felipe, Dandara e Carlos para uma mesa, na qual estava o conhecido empreendedor da música e professor de empreendedorismo, Tubarão. Tinha morado em países latinos, aprendendo e trabalhando com carreiras de artistas da música. Papo vai, papo vem, entre um samba e outro, trocaram muitas informações sobre dicas de como ganhar dinheiro através da internet, do marketing, da formalização de pessoa jurídica, da orientações sobre a carreira e da identidade da comunidade. Foram várias informações sobre o empreendedorismo musical. Felipe ouvia algumas coisas do papo, mas estava muito descrente e sonolento. Tubarão não parava de falar e falava de forma "difícil". Baixinho, Felipe falava algo para Carlos.

Felipe: Como assim precisamos levar em conta a identidade da comunidade para que nossa banda tenha sucesso? O Nordeste está cada vez mais violento. Esse Tubarão, sei não.

Tubarão, ouviu o comentário de Felipe. 
Tubarão: Você é Felipe, certo? Deixa eu te falar algo. Não é fundamental que você leve em conta a identidade da comunidade para ter sucesso. Mas, eu penso que você mora em um bairro, não é? Algum daqui do Nordeste?

Felipe: Moro no Vale das Pedrinhas.

Tubarão: Eu sou nascido e criado em outro bairro de Salvador. Sei que o Nordeste é um local, que possui muitos artistas e projetos empreendedores interessantes. Vejo pelos jornais que a violência é uma grande complicação para o Nordeste e muitos territórios periféricos. A identidade da comunidade é muito forte. Aqui no bairro, existem duas artesãs que fazem bonequinhas negras, com instrumentos percussivos, vocês conhecem? A negritude e a percussão fazem parte daqui, não é? Esse tipo de ação pode fazer muito bem ao bairro. Esse tipo de identidade não é uma prisão. Pelo contrário, oferece várias pistas legais para integrar na sua arte. Quando pego as características, práticas, competências e outras coisas de uma identidade, eu posso enriquecer meu trabalho. Ele fica original para os outros que fazem sempre igual, percebe? Se eu divulgar a comunidade para o mundo, isso ajuda a economia local se desenvolver.

Nesse momento, Felipe passou a assistir apenas o show, meio sonolento. Era muita informação. Ele não estava acreditando muito nesse papo de "identidade da comunidade". Bebeu um pouco demais e estava cansado do trabalho. Acabou cochilando.

Denny: Fantástico, Tubarão! Quer dizer que se a gente fala do nosso bairro nas nossas músicas ou pensa nele para compor nossa melodia, é possível que desperte um interesse maior das pessoas pela comunidade?

Tubarão: Claro, Denny! Se pessoas de outros bairros vem aqui, a economia criativa vai ser aquecida. A produção envolvendo arte e criatividade aquece a economia de comida, bebida, pousadas e muitas outras. Nas minhas andanças pelos países aqui da América do Sul, percebi que as histórias e jeitos da minha comunidade eram muito valorizados pelo pessoal de lá, porque era diferente e divertido. Eu sempre fiquei ligado nas culturas de outros países, nas identidades das comunidades. la aprendendo para tentar melhorar os meus trabalhos.

Carlos: Isso pode melhorar nosso crescimento artístico, gerar novos projetos e mais trabalho para o bairro.

Felipe: Muito legal, Tubarão. Tive muitas ideias para ajudar na nossa carreira.

Tubarão: Mas, não esqueça: você tem que pensar, também, na identidade cultural da comunidade. Olha quem está chegando, Mr. Armeng, um artista que valorizo muito. Armeng, fala um pouco da sua história. Esses jovens estão com vários projetos.

Mr. Armeng: Oi pessoal, tudo bem? Sou Mr. Armeng. Canto, produzo música e cultura há alguns anos. No começo, foi muito difícil. Via oportunidades de conseguir financiamento para fazer show e CD. No entanto, no início, não sabia como escrever um projeto. Denny e Marquinhos podem falar melhor sobre essas experiências...
Denny: Todos temos algo para ensinar, não é? Sem saber como escrever um projeto, o que você fez?

Mr. Armeng: Eu vi um concurso de música na TV. Reuni uma galera que fazia um som comigo, nos inscrevemos e ganhamos! Foi um concurso massa, porque aprendi muito sobre música e produção musical. Depois do concurso, passei a produzir minha música e a de outros artistas do bairro. Corri atrás de cursos na internet sobre produção cultural, para começar a fazer eventos na comunidade. Fui metendo as caras, até conseguir ganhar um edital do Governo do Estado.

Felipe: Sensacional, Armeng! Quanto você cobra para produzir uma música para minha banda?

Mr. Armeng: Hoje não estou fazendo nenhuma produção musical. Estou focado na produção do meu novo $C D$ e de uma oficina de RAP e grafite para o bairro e as Escolas Públicas de Salvador. Tem que ficar ligado em ajudar sua comunidade. No início, não é fácil. É muita ralação. Vida de empreendedor, até se ajeitar, quando é ajeitada, tem muitas dificuldades, como falta de dinheiro, de conhecimento, de parcerias. Ainda mais para o povo das quebradas, das periferias. Muita gente que deveria chegar, não está chegando. O truque é correr atrás e ser o que todo empreendedor deve ser: resiliente! Ou seja, se tomar uma porrada, cair, levantar e correr atrás! Resiste!

Carlos: Temos dificuldades para focar na nossa carreira, porque a gente trabalha de segunda a sábado. Ficamos muito cansados, sabe? Tem as dívidas, a falta da grana...

Mr. Armeng: A diferença consiste em não ser derrubado pelas dificuldades. É preciso ajudar quem está começando, quando vocês estiverem melhores, como Denny e Marquinhos fazem no DM de Boa. Com o conhecimento que vocês já têm, já podem ajudar outros jovens que não têm nenhuma noção do que fazer para a carreira musical dar certo.

Felipe: Oxente, Armeng! A gente mal começou nossa carreira e já tem que pensar em ajudar?

Dandara: É verdade, Armeng. Concordo com Felipe.

Denny: Pessoal, vocês precisam entender que ajudando a comunidade vocês se ajudam. Todo mundo ganha!

Marquinhos: Claro, gente. Eu e Denny estamos pensando em fazer um projeto para ensinar empreendedorismo para os jovens. $\mathrm{O}$ Governo lançou um edital para isso. A música chama os jovens para o nosso projeto, mas como ensinar essas dicas de financiamento, de marketing, de elaboração de projetos? Uma fala assim como a sua é legal, mas o dia todo, só de papo, eles não aguentam.

Tubarão: Seria legal unir o que os jovens mais gostam, música e arte em geral, com empreendedorismo. Que tal?

Mr. Armeng: Boto fé no que Tubarão está dizendo. O caminho é esse: ensinar na linguagem que nós, artistas, curtimos. Foi um prazer estar aqui, contribuindo para a carreira de vocês, nesse papo. Lembrem sempre dos seus! Lembrem que a cultura do bairro, da cidade é muito importante para ter sucesso na arte. Deixa eu ir. Vou fazer um show do outro lado do bairro. 
Tubarão: Se ligaram, pessoal? A cultura é fundamental para que o empreendedorismo cultural tenha sentido. A cultura, além de alimentar o empreendedorismo cultural, promove lazer, conhecimento e pode tirar jovens da violência, do desemprego, do ócio e da ignorância sobre diversos aspectos da vida e da sociedade. Hoje, o bom empreendedor não é aquele que busca vencer sozinho. A vitória é de toda a comunidade. Contem comigo para o que precisarem. Olhem só, a banda vai começar a tocar.

$\mathrm{O}$ trio de músicos ficou animado. No dia seguinte, se reuniram na casa de Carlos e começaram a pensar nos próximos passos da banda.

Felipe: Que tal pensarmos no site da banda? Vamos lançar, naquele site, a proposta de que Tubarão falou?

Dandara: Acho legal, mas, vamos incluir o Nordeste na produção de nossa banda? Podíamos colar com Denny e Marquinhos e pensar um projeto de educação para o empreendedorismo. Vocês visualizam?

Felipe: Isso, vemos depois. O mais importante agora é a nossa banda. Temos que correr atrás do nosso.

Carlos: Concordo com Felipe. Vemos, primeiro, o nosso caminho, depois, o dos outros.

Dandara: Felipe, você não se ligou ainda. Se começarmos apenas com a nossa banda, pensando apenas em nossas carreiras, podemos até ter sucesso. E a comunidade? Ontem, Tubarão explicou que o empreendedorismo cultural é diferente do empreendedorismo focado em interesses individuais. Carlos, você também, se liga! Só depois que alcançarmos o sucesso vamos pensar em algo para o bairro? Nossas músicas não vão ter algo da identidade do Nordeste? Mesmo se falamos do bairro em nossas músicas, está muito fraco, sem força. Precisamos fortalecer nosso bairro para ter mais força em nossas músicas!

Felipe: Legal! Músicas que falam do nosso bairro. Assim, chamamos mais atenção da mídia e vamos "bombar" na internet, na televisão!

Dandara: Agora, vamos imaginar se todos os músicos daqui soubessem dessas dicas sobre empreendedorismo cultural? Pense na comunidade, amigo.

Felipe: A ideia é boa. Mas, não temos grana! Acordem!

Carlos: Cara, o que fazemos? Não tem como fazer um projeto sem grana. Como fica o material para as aulas? E o pagamento dos educadores?

Dandara: Agora, vocês me pegaram. Vamos precisar de ajuda.

\subsection{Empreender é Desbravar}

O trio de músicos marcou um encontro com Tubarão. Depois de três tentativas frustradas, por conta dos compromissos profissionais dele, conseguiram chamar também Denny e Marquinhos, com dificuldades, pois estavam em final de turnê. No dia do encontro, Felipe e Carlos disseram que tiveram uma emergência e não poderiam comparecer. Tubarão também desmarcou em cima da hora. Denny, Marquinhos e Dandara conseguiram, finalmente, se reunir. Levantaram possibilidades de recursos privados, públicos e coletivos. Ficaram de pensar que caminho seguir com Felipe, no próximo encontro.

No próximo encontro, após muito diálogo, decidiram pela ideia de colocar o projeto em um edital público. Dessa vez, Felipe, Carlos e Tubarão apareceram.

Felipe: A ideia de Denny e Marquinhos é muito legal. Mas, acabo de conseguir um contato com uma grande marca de refrigerantes. Eles querem patrocinar um curso de como fazer refrigerante e uma apresentação final com música pop! Querem três músicas: duas em inglês, com muita música eletrônica.

Carlos: Poxa, legal que uma empresa grande quer nos ajudar. Adorei a ideia.

Tubarão: É, parece razoável.

Dandara: As músicas têm que ser em inglês? A gente não decidiu que ia cantar em português? Lembra do fiasco que foi aquela apresentação no barzinho, quando a gente só cantou em inglês?

Denny: Só cantamos em português. E essa história de música eletrônica? Acho legal, mas não devíamos focar na percussão e no samba, que são a cara do Nordeste? O projeto não é para incluir a comunidade?

Felipe: Pessoal, essa é uma oportunidade única. Primeiro, fazemos isso, depois, pensamos na comunidade, na identidade, no ensino do empreendedorismo...

Marquinhos: Felipe, você é muito ganancioso. O "DM de boa" não vai se meter em um esquema que prejudique a comunidade. Quer ganhar seu dinheiro dessa forma, vá ciscar por outras bandas!

Felipe: Certo. Carlos, e você?

Carlos: Marquinhos, eu te respeito muito. Mas, isso não é ganância. É oportunidade! Estou com Felipe.

Tubarão: Essa proposta da marca no Nordeste é sensacional! Essa empresa de refrigerantes sabe como o território é incrível pelas suas artes, pela sua identidade. Vão ajudar muito! Pode ajudar, principalmente, nos meus... quer dizer, nos nossos projetos.

Felipe: Gente, é uma oportunidade única. Se vocês não querem, eu vou nessa. Dandara, vai comigo?

Dandara: Amigo, não te apoio nessa. Tubarão, como assim é uma ótima oportunidade? Você não falou sobre valorização da comunidade? O que Marquinhos disse faz sentido. Esse projeto é oportunista e desonesto com a comunidade. Não estou reconhecendo vocês, Felipe e Carlos. Onde estão os caras que queriam cantar para a comunidade?

Felipe: Eu evoluí, Dandara. Boa sorte para vocês com o projeto de educação.

Carlos: Sucesso, gente! Essa oportunidade não posso deixar passar.

Tubarão: Estamos valorizando a identidade cultural local. O fato do projeto acontecer no Nordeste, é tudo de bom. Vai ser ótimo para minha carreira! Abraços e boa sorte para vocês!

Felipe, Carlos e Tubarão saíram do encontro. Denny, Marquinhos e Dandara ainda pensavam sobre o projeto educacional. Se perguntavam: tentar financiamento público para um projeto educacional seria, de fato, uma boa ideia? 
Marquinhos: A situação de Felipe pode nos motivar ainda mais para ganhar o edital e fazer esse projeto acontecer!

Dandara: Estou triste com essa postura de Felipe e Carlos. Eles são grandes amigos. Não sei como vai ficar a banda.

Denny: Eu te entendo. Tubarão me decepcionou. Mas, vamos pensar em nosso trabalho, em como ganhar dinheiro para ajudar a comunidade.

Marquinhos: Denny, não seria forçar a barra fazer isso agora? Dandara está mal.

Após dois dias de recuperação de Dandara, combinaram uma reunião para analisar o edital de financiamento. Estudaram o edital em vários encontros. Decidiram focar em dois aspectos para elaborarem o projeto: a importância da identidade cultural do Nordeste e como essa identidade pode ser potencializada, no bairro, através do empreendedorismo cultural.

Denny: Precisamos colocar no projeto as maravilhas do ensino do empreendedorismo. Vamos qualificar os jovens artistas estimulando as artes.

Marquinhos: Concordo. Mas, temos que colocar os desafios. Se não, fica muito "conto de fadas" e os avaliadores do projeto não vão acreditar no que estamos propondo.

Dandara: Isso mesmo. Temos motivo e vamos focar no empreendedorismo e no uso das artes para educar para o empreendedorismo.

Marquinhos: Se o projeto passar, quem vai ensinar o empreendedorismo através das artes?

Denny: Oxente, Marquinhos. Você pode ensinar conhecimentos sobre como empreender. Juntamos com o que já sabemos em nossas carreiras.

Marquinhos: Claro! Ótima ideia!

Dandara: $O$ que vocês acham da fazermos uma grande apresentação para a comunidade? Poderíamos fazer músicas com os conhecimentos que a gente aprendeu...

Denny: Legal! Tem diversão e, ao mesmo tempo, os artistas podem mostrar seus trabalhos. Quem participar do curso pode preparar artes com dicas sobre o empreendedorismo. Assim, estimula os moradores do bairro a ganharem dinheiro com seus trabalhos, suas artes!

Marquinhos: Acho que temos um esboço do projeto! Tenho um desafio para vocês. Por que, além de submeter o projeto para um edital, não começamos a colocar em prática? Pode ser com poucos jovens. O que acham?

Todos concordaram. O projeto foi redigido e submetido. $\mathrm{O}$ resultado será divulgado dentro de seis meses. Durante um mês, Dandara, Marquinhos e Denny trocaram vários conhecimentos empreendedores e estudaram novos conhecimentos. Já preparados para ensinar os conteúdos, Denny, Marquinhos e Dandara convidaram 30 jovens artistas para o curso. Conversaram com eles sobre as necessidades que tinham em suas carreiras. A partir desses relatos e dos conhecimentos empreendedores, que identificaram, compuseram duas músicas sobre conhecimentos empreendedores, que achavam importantes serem divulgados no bairro. Enfim, chegou o dia do início das aulas.

Denny: Pessoal, bem-vindos! Eu sou Denny e hoje vamos aprender sobre como empreender na cultura.

José: Mais um cara que vai encher a gente de blábláblá! - Reclamou em voz alta, José, um dos jovens participantes.

Marquinhos: José, o que menos vamos ter aqui é "blábláblá". Vamos aprender sobre empreendedorismo cultural através de músicas! Fizemos duas músicas sobre nosso primeiro conteúdo: a identidade do empreendedor da cultura!

José: Empreendedorismo? É sobre como abrir seu negócio? Eu ajudei a montar o curso com o vereador Luiz sobre pães e como abrir uma padaria. Que história é essa de música? Isso é o que, educação ou show? Se é show, onde está a cerveja?

Dandara: José, queremos fazer algo diferente. Queremos ensinar e aprender com todos vocês. Vamos focar nas produções artísticas e culturais de cada um de vocês para que juntos, possam ajudar o Nordeste, inclusive o comércio local.

Denny: Queremos aprender sobre empreendedorismo cultural e fazer arte.

Dandara: É, José. Com a música, compondo a letra, as melodias, nós aprendemos mais sobre o assunto. Ficamos com mais vontade ler mais e saber mais.

José: Ah bem! Achava que vocês iam copiar meu curso com o vereador Luiz. Mas, não me convenci ainda sobre a música. Toquem aí para eu ver.

Denny, Marquinhos e Dandara embalaram a seguinte música:

"Brasileiro, alegre guerreiro, conquista o pão de cada dia

O novo cancioneiro, fala do Nordeste de Amaralina

Nordeste que está nas mãos, nos pés e na cabeça

Dona Joana e Seu Zé empreendem, com certeza,

Vendem geladinho, picolé e sorvete

Tem Tania e Zé, do salão de beleza

E o grande Mr. Armeng, que manda o RAP com firmeza

Começou de baixo, ralou pra caramba

No final, aprendeu sobre empreender e fez um samba

Todo empreendedor tem que meter as caras

Acreditar nos sonhos, se qualificar e resistir

Hey, galera, vamos viabilizar os sonhos e curtir!"

José: Bacana! Lembrou da minha mãe, que utiliza materiais reciclados para fazer flores. Artesanato, não é?

Denny: Isso! Sua mãe vende flores artesanais, inspiradas nas flores do Nordeste, não é? Ela é uma empreendedora cultural!

José: Massa! Mas, e quando eu faço um show com minha banda? Estou empreendendo? Eu sou um empreendedor cultural?

Marquinhos: De certa forma, é sim. O que estamos aprendendo com vocês são outros conhecimentos sobre empreendedorismo cultural. Por exemplo, eu não sabia que o empreendedor cultural deveria se importar com o que o bairro precisa e nem que era preciso fazer algo coletivo. Aprendi faz pouco tempo. 
José: Eu me importar com o bairro? Por quê? O que vou ganhar com isso?

Antônio: Eu me chamo Antônio. Moro no bairro vizinho. Se a gente se importa com o bairro e se fazemos um trabalho coletivo, nosso bairro e nossa arte crescem, não é?

Denny: Exatamente! Considerando a identidade do nosso bairro, o empreendedorismo cultural valoriza essa transformação social dos bairros, incentiva o trabalho coletivo. Com isso, dá mais força aos projetos de cada um e de todos, pois parte dos conhecimentos, gostos, práticas dos moradores do nosso bairro. Quem melhor que nós, que nascemos, crescemos e vivemos aqui para dar um impulso aqui?

Dandara: Podemos apresentar outras músicas para vocês?

Após a segunda apresentação das músicas sobre conhecimentos empreendedores, Dandara, Marquinhos e Denny fizeram uma dinâmica de leitura de um texto, que tratava da identidade empreendedora e dos tipos existentes de empreendedorismo. Ouviram músicas que falavam das duras realidades das cidades e bairros periféricos. Samba, RAP, reggae, rock e MPB foram alguns dos gêneros musicais. A dinâmica serviu para que cada um escolhesse a música com que mais se identificava, explicasse por que se identificava com a música. Dessa forma, o grupo de jovens pôde se conhecer melhor, no primeiro encontro do curso. Além disso, cada participante se comprometeu já com o "perdão antecipado", ou seja, se preparou para as divergências e conflitos que poderiam acontecer, bem como os perdões que deveriam exercitar, caso necessário. Essa prática prepara o grupo para as adversidades e busca evitar que conflitos tomem grandes proporções, ameaçando a integração do grupo e a realização do projeto.

Depois do primeiro mês, com leituras e músicas, aprenderam sobre carreiras, identidade, marketing e aspectos legais da música para jovens músicos. Faltavam ainda cinco meses de aprendizagem. Dos 38 jovens músicos que foram convidados, somente 23 vieram na primeira semana. Desses, apenas 18 jovens permaneceram. Eram 10 jovens do Nordeste e 8 jovens de outro bairro.

Marquinhos: Estou preocupado. Temos tão poucos participantes.

Denny: Não se preocupe. Todo processo de educação pode ter dificuldades. É normal. Vamos entrar no terceiro mês do projeto. Faltam somente alguns conteúdos. São apenas dezoito jovens, mas são engajados. Participam das aulas e aprendem a importância da identidade cultural da comunidade para fazer o projeto dar certo. Não é mesmo?

Dandara: Concordo. Acho que o que está dando certo é que estamos trabalhado com uma linguagem que a juventude tem afinidade.

Denny: Com certeza, Dandara! Imagina se fosse uma linguagem artística, o pessoal não curte nem domina..

Marquinhos: Teríamos que envolver outros parceiros, não é? Por exemplo, Maria, que é professora de cinema...
Dandara: Boa ideia! Por que não a chamamos para se juntar a nós? Ela pode ajudar a conhecer melhor as formas de divulgar o trabalho artístico?

Denny: Legal! Ela pode se interessar e já pode se elaborar um filme para a nossa apresentação final. Um filme para ajudar o empreendedor divulgar melhor seus trabalhos.

Maria foi convidada. Ficou muito feliz, aceitou e sugeriu fazer um musical, aliando cinema e música. Ela se interessou pela temática do marketing para o setor cultural. Planejaram filmar um curta-metragem com expectativa de exibição para a comunidade durante a apresentação final.

\subsection{Os Sonhos se Encontram}

Foram meses de ensino e aprendizagens sobre diversos temas do empreendedorismo cultural. No penúltimo mês, com vários aprendizados, os jovens músicos estavam animados. Pelas suas carreiras e pelas possibilidades para o Nordeste, o curso estava caminhando bem. A apresentação da turma, para a comunidade, foi marcada para o final do mês, no dia de divulgação do resultado do edital.

O telefone de Dandara toca

Dandara: Alô?

Felipe: Oi, Dandara. É Felipe. Tudo bem? Como está o seu projeto?

Dandara: Está bem, bombando!

Felipe: Soube que tinham poucos participantes. Não se preocupe, projeto educacional é assim mesmo.

Dandara: E seu projeto, como está?

Felipe: Incrível! São cem jovens envolvidos. Cada um tem direito a uma bolsa de 100 reais. Já aprendemos a fazer refrigerante. É viciante de tão bom! No fim do mês, fazemos nosso show pop com uma pegada internacional. Estão todos convidados!

Dandara: Espera, fim do mês? Vai ser nossa apresentação!

Felipe: Muito bom! Vão ser duas opções de apresentações para a comunidade. Abração. Nós nos falamos depois.

Telefone desligado. Dandara contou para Denny e Marquinhos o que tinha acontecido. Ficaram apreensivos da apresentação deles ficar esvaziada. Mas, decidiram não desistir.

Dandara: Pessoal, hoje a gente coloca a mão na massa para a nossa apresentação.

José: Estamos indo bem. Temos vinte músicas criadas. Trouxe algumas ideias para a apresentação. Podemos decorar com balões azuis. Quem começa a tocar é o grupo.

Enquanto José ia definindo como seria a apresentação da turma, o que cada um iria ter que fazer e a ordem de apresentações, todos se entreolharam.

Dandara: Desculpe te interromper, José, mas são ideias, não são? Vamos ouvir as ideias de todos.

Antonio: Concordo com Dandara. O aprendizado foi só seu, José?

José se desculpou. Mas, o clima ainda estava tenso. Todos ficaram mais tranquilos, quando os detalhes das apresentações 
foram organizados. Cada jovem se inseria na temática na qual estava interessado para ajudar.. Em seguida, compunham mais músicas com as temáticas empreendedoras. Todos estavam ansiosos, com receio do tempo passar rápido. No decorrer das semanas, todos dialogaram muito, no facebook e no grupo do Whatsapp. As situações foram bem administradas. As decisões eram coletivas. Cada um sentia que, conforme iam compondo, mais liam sobre os assuntos e mais aprendiam sobre 0 empreendedorismo. Percebiam que os seus sonhos não eram isolados. Eles se encontravam no sentido de viver de música e ajudar suas comunidades. Músicas compostas coletivamente, brincadeiras de rimas e improvisações fizeram parte de todo o processo de educação e de planejamento da apresentação final. Todos se animavam, cada vez mais, com o processo de aprendizagem e de planejamento da apresentação. O dia da apresentação chegou.

Denny: Nossa apresentação é amanhã. Está tudo organizado, não é?

Dandara: Sim, tudo certo!

José: Ótimo! Fico feliz que vocês tenham me escolhido para ser mestre de cerimônias. Nossa apresentação vai bombar!

\subsection{O Desbravamento não Terminou}

Era o grande dia. No início da manhã, todos os jovensprodutores estavam presentes no salão de eventos da associação de moradores. O som estava sendo arrumado, tudo estava pronto. $\mathrm{Na}$ hora marcada, quinze pessoas marcavam presença. Eram parentes de Denny, Marquinhos e Dandara. A maioria da comunidade estava no evento da marca de refrigerantes. Tensão. Resolveram começar logo a apresentação. Teve início a apresentação, então, com uma dupla de rappers, que fez parte do curso. Cantaram uma música autoral sobre a importância da identidade do bairro e contra a violência policial. Foram chegando, mais umas dez pessoas. Os rappers continuaram cantando uma música sobre dicas de recursos públicos para artistas. Mais cinco pessoas chegaram.

Dandara: Está dando tudo certo. O público está chegando!

Denny: Será que o evento de Felipe não está indo bem?

Marquinhos: Mas, ainda são poucas pessoas.

Dandara: Acabo de saber que algumas pessoas estão reclamando do evento da marca porque tem muita música em inglês e está difícil de entender...

José: Será que esse pessoal vem para cá?

Dandara: Espero! Daqui a cinco minutos é a hora de exibirmos o curta-metragem sobre marketing cultural. Está no ponto?

José: O filme não vai ficar pronto a tempo. A professora que dirigiu disse que atrasamos muito as filmagens com uma discussão sobre quem ia aparecer. Por isso, só vai ser possível exibir o filme no mês que vem.
Marquinhos: E agora? Por que não avisaram antes? Temos 20 minutos sem nenhuma apresentação prevista. O que vamos fazer?

Silêncio e tensão. A exibição do curta-metragem era de vinte minutos. A diretora não compareceu com raiva da situação. Nenhum dos participantes comentou o caso. Não sabiam o que fazer.

Denny: Vamos ter que fazer o que muitos empreendedores fazem: improvisar!

Dandara: Improvisar?

Antonio: $E$ se fizermos um show de rimas com empreendedores? Podemos envolver o pessoal do curso, jovens que empreendem da plateia, empreendedores que estão vendendo as comidas e bebidas.

José: Que maluquice. Não sei se vai rolar. Acho melhor a gente falar a verdade para o público. Falhamos com o que estava previsto na programação. Nesse tempo, poderiam ir ao banheiro.

Dandara: Achei a ideia de Antonio incrível.

Os jovens-produtores aderiram à ideia de Antonio e anunciaram que por problemas técnicos, o curta não seria exibido. Entretanto, fariam um concurso de rimas empreendedoras. Na hora de apresentar, procuraram José, mas Dandara falou que ele ia embora. E agora, quem substituirá o mestre de cerimônia? Denny pegou o microfone e tomou a iniciativa de conduzir o concurso. Quem participava e quem assistia se divertia e aprendia com a apresentação.

Em seguida, duas bandas de samba e reggae, do bairro vizinho, falaram sobre a carreira na música e as dificuldades de fiscalizarem os direitos autorais. Até então, ninguém tinha chegado, mas ninguém tinha ido embora. O público era de jovens, idosos, crianças e diversas pessoas da comunidade. Todos se divertiram com as músicas e as apresentações. Três vendedores de alimentos saciaram a fome e sede do público. Depois que tudo terminou, Marquinhos acessou a internet para saber se o projeto tinha sido aprovado.

Denny: E aí, nosso projeto foi aceito?

Dandara: Fala logo, Marquinhos!

Marquinhos: Nosso projeto não passou. Alegaram que está muito vago. Que precisava ser mais detalhado no orçamento, nas atividades e na estratégia de divulgação.

Denny: Uma pena. Mas, com essa experiência, temos mais chance de conseguir na próxima. Não é?

Dandara: Verdade, ,mas, a gente se esforçou tanto.

Marquinhos: Sobre José, ele disse o que aconteceu?

Dandara: Ele ficou chateado com a improvisação. Disse que as coisas têm que ser planejadas e foi embora. Falou que trabalhar com muita gente é muito confuso.

Marquinhos: Em qualquer atividade, é possível que algumas pessoas desistam, se revoltem contra o processo. Com minha experiência, sei que muito imprevisto pode acontecer. Tenho lido sobre o assunto. 
Dandara: Marquinhos, estou achando você muito conformista. José estava desde o início do projeto. Você está achando tudo "muito lindo", "normal". Não é assim. Não podemos aceitar essas coisas.

Marquinhos: Dandara, você tem razão. Mas, pense no que te falei sobre o processo de educação. Falando em educação, me lembrei da falta de educação. Como foi o evento de Felipe, Tubarão e Carlos?

Denny: Deu muita gente! Ouvi que foram trezentas pessoas.

Dandara: Poxa, o nosso podia ter sido assim.

Marquinhos: Mas, estamos fazendo um projeto com uma proposta educacional, sem grandes patrocínios. Tivemos umas cinquenta pessoas!
Dandara: É, por esse lado, você tem razão.

Dandara, Marquinhos e Denny, com o conhecimento que adquiriram durante todo o processo, resolveram se juntar ao projeto social "DM de Boa". Começaram a estudar um outro edital para ampliarem o projeto com o ensino do empreendedorismo através das artes, em todos os bairros, que compunham o Nordeste. Felipe e Carlos se mudaram do Nordeste e estavam em negociação com uma gravadora para lançarem um CD de música pop internacional. Tubarão virou garoto propaganda da marca de refrigerantes. Cada artista seguia seu caminho.

${ }^{2}$ Gíria baiana, similar a "ô, gente". 